\section{Latour i literaturoznawstwo}

Rita Felski
Źródło: Rita Felski, Latour and Literary Studies,

"PMLA", maj 2015, nr 3, t. 130 , S. $737-742$.

TEKSTY DRUGIE 2021, NR 2, S. 204-213

DOI: 10.18318/td.2021.2.12 | ORCID: 0000-0001-6493-3668

$\mathbf{I}_{\mathrm{i}}^{\mathrm{n}}$ nteresuję się zagadnieniami związanymi z czytaniem i interpretacją. Moje zaciekawienie budzą również teoria aktora-sieci i prace Brunona Latoura. Czy te zainteresowania da się połączyć? Czy teoria aktora-sieci może nam pomóc w myśleniu o interpretacji? Czy pozwala uczynić z nas lepszych czytelników? Jak literaturoznawstwo i koncepcja Latoura przyciągają się nawzajem, jak znajdują wspólny język, jak się uwodzą lub rozmijają? Jakie rodzaje pojedynków, rywalizacji, intryg albo romansów wynikną z tego spotkania?

Choć Latour przyznaje, że ma dług wobec Greimasowskiego modelu aktora czy też aktanta, to jego uwagi na temat literaturoznawstwa były do tej pory raczej zdawkowe. Ignoruje on lub wprost odrzuca wiele tematów, które w ostatnich dekadach zaprzątały głowy literaturoznawców: reprezentacja, zwrot lingwistyczny, tekstualność, symboliczność, negatywność, inność. Pod pewnymi względami koncepcja Latoura opiera się
Rita Felski - prof. pracuje na University of Virginia, była redaktorka "New Literary History".

Zajmuje się zagadnieniami związanymi ze współczesną teorią literatury, w tym relacjami między literaturoznawstwem a teorią aktora-sieci. Autorka między innymi Hooked: Art and Attachment (2020), The Limits of Critique (2015). 
próbom uczynienia z niej ogólnej metody. W dialogu ze Splatając na nowo to, co społeczne bezradny doktorant odwiedza profesora, który jest literackim wcieleniem Latoura, szukając porady, jak zastosować teorię aktora-sieci w doktoracie, ale na każdym kroku natrafia na nową przeszkodę. Okazuje się, że teoria aktora-sieci jest nie tyle teorią na temat tego, jak badać rzeczy, ile „jak ich nie badać. Albo raczej, w jaki sposób zapewnić aktorom możliwość wyrażenia się"'. Czy da się pogodzić ten radykalny empiryzm - jak określa go Latour, nawiązując do Williama Jamesa - z literaturoznawstwem nastawionym na teorię i tekst? Szczególnie w jaki sposób ów empiryzm mógłby nam pomóc przemyśleć na nowo praktyki czytania i interpretacji? Na pierwszy rzut oka perspektywy nie wyglądają zachęcająco.

Mimo to pakt o wzajemnym nieingerowaniu dobiega końca, ponieważ koncepcja Latoura wzbudza wśród literaturoznawców coraz większe zainteresowanie. Najbardziej ożywcze pola badawcze w badaniach literackich dotyczą studiów nad zwierzętami, teorii rzeczy, myśli ekologicznej i posthumanizmu - wszystkie one opierają się na założeniu współzależności aktorów ludzkich oraz pozaludzkich. Latour i przedstawiciele tych nurtów zajmują się podobną problematyką, dlatego coraz trudniej unikać odwołań do teorii aktora-sieci, niezależnie od tego, czy traktujemy ją jako sprzymierzeńca czy rywala, którego należy potępić. Latour odrzuca podziały podmiot/przedmiot, natura/kultura, myśl/materia i język/świat, zakładając tym samym równowagę ontologiczną między wszystkimi rodzajami bytów we wspólnie skomponowanym świecie. Stąd bierze się retoryczna siła „litanii Latoura”, tj. quasi-surrealistycznej listy różnorodnych bytów: truskawek, pluskwiaków, kwarków, psów rasy corgi, tornad, Tin Tina i kapitana Baryłki, które dzięki wielorakim związkom i współobecności są traktowane na takich samych warunkach. W ten sposób a k t o r nie jest obarczany przypisanymi mu z góry intencjami, świadomością bądź autonomią, termin ten oznacza po prostu dowolne zjawisko, którego istnienie stwarza różnicę.

Aktorzy nie istnieją sami w sobie, lecz tylko za pośrednictwem sieci powiązań. W podejściu Latourowskim więzi nie ograniczają działań - one je umożliwiają. Ważne jest nie rozróżnienie na wolność i zniewolenie, lecz podział na różne rodzaje związków: „w przypadku emancypacji - nie oznacza

1 B. Latour Splatajqc na nowo to, co społeczne. Wprowadzenie do teorii aktora-sieci, przeł. K. Abriszewski, A. Derra, Universitas, Kraków 2010, s. 204.

2 I. Bogost Alien phenomenology; or, What it's like to be a thing, University of Minnesota Press, Minneapolis 2012. 
ona «wolny od więzi», ale dobrze-połączony"3. Teoria aktora-sieci polega zatem na śledzeniu wszystkich ścieżek, dzięki którym różnego rodzaju aktorzy - od przegrzebek po metro, od antylop po materace do łóżka - są tworzeni dzięki relacjom. Ze względu na hybrydowy charakter tych sieci każda przekazywana w nich rzecz jest zarazem przekładana, przenoszona i przekształcana. Nie dziwi zatem, że teoria aktora-sieci jest określana czasem jako socjologia mediacji.

Tendencja do umieszczania różnych bytów na tym samym poziome ontologicznym przez wplatanie ich w sieci powiązań utrudnia wykorzystanie teorii aktora-sieci jako metody literaturoznawczej. Co miałoby wyróżniać w takim podejściu literaturoznawstwo? Jak latourowski sposób myślenia mógłby się połączyć z zainteresowaniami większości literaturoznawców? Jak może nam pomóc w czytaniu? Teoria aktora-sieci z pewnością odznacza się pewnymi podobieństwami do rozwijającej się ekologii kulturowej oraz do badań kulturowych i ich metod wyrazu ${ }^{4}$. Na pierwszy rzut oka wydaje się jednak, że daleko jej do tradycyjnych zainteresowań i metod literaturoznawczych, takich jak interpretacja. Dlatego interakcje między Latourem a literaturoznawstwem przypominają jednostronny pojedynek wrestlingowy, którego wynik został z góry ustawiony przez obrotnych agentów. Albo wykorzystujemy wątki wzięte z teorii aktora-sieci w istniejących już praktykach close reading (literaturoznawcy śledzą ruch i powiązania aktantów w obrębie dzieł literackich), albo teoria ta prowadzi nas w stronę socjologii sieci, która bywa niezwykle pouczająca, ale wydaje się odległa od literaturoznawczych problemów interpretacyjnych. Czy możliwa jest bardziej zbalansowana forma interakcji?

Najnowsza książka Latoura mierzy się właśnie z tym pytaniem. Dumając nad wpływami i dziedzictwem teorii aktora-sieci, Latour zauważa ze smutkiem, że antropolog/antropolożka sieci „traci w szczegółach to, co zyskał/a dzięki swobodzie poruszania się [...]. Kiedy bada Prawo, Naukę, Ekonomię bądź Religię, zaczyna czuć, że o wszystkich nich mówi niemal to sa mo, mianowicie że «składają się z heterogenicznych i niespodziewanych elementów, ujawnianych w toku analizy»"5. Latour dotyka tu problemu, o którym

3 B. Latour Splatając na nowo, s. 318.

4 Zob. np. interesujące podejście Franka Kelletera do Prawa ulicy, traktowanego jako tekst współtworzony przez sieci sprawczych podmiotów. F. Kelleter Serial agencies: the wire and its readers, Zero, Winchester 2013.

5 B. Latour An inquiry into modes of existence: an anthropology of the Moderns, transl. C. Porter, Harvard University Press, Cambridge, MA 2014, s. 35. 
pisałam powyżej: nadmierne podkreślanie różnorodnych związków między wieloma aktorami prowadzi do zatracenia istotnych różnic. Jak moglibyśmy uwzględnić pluralizm i wzajemne powiązania mnogości zjawisk, honorując jednocześnie najważniejsze różnice między sieciami, na które te zjawiska się składają? Jak uchwycić zarówno mieszaniny aktorów, jak i kontrasty między nimi? Pójście w tym kierunku wydaje się konieczne, jeśli koncepcja Latoura ma odpowiedzieć na problemy literaturoznawcze zadowalająco.

Latour wprowadza pojęcie „sposobów istnienia” (wzięte od Étienne'a Souriau), aby opisać różnice między nauką, prawem, techniką, religią i sztuką. W przeciwieństwie do metafor kartograficznych, takich jak pole czy domena, kojarzących się z wprowadzaniem rozgraniczeń, sposoby istnienia wskazują na różnice bez zakreślania granic. Możemy się zgodzić, że teksty literackie łączą się z niezliczoną ilością rzeczy nieliterackich, a jednocześnie przyznać, że wokół literatury skupiają się określone sposoby mówienia, doświadczania, działania, interpretowania i oceniania. Przede wszystkim - zauważa Latour - musimy mówić o tych sposobach istnienia ich własnym językiem: używać ich kryteriów weryfikacji i oceny, ich warunków fortunności i niefortunności. Jego koncepcja opiera się zarazem na propozycji wprowadzenia nowych opisów: teorie, które dotychczas formułowaliśmy na temat różnych sposobów istnienia, często nie pasują do naszych doświadczeń i praktyk.

Ta argumentacja pasuje do moich zainteresowań związanych z używaniem literatury: $\mathrm{z}$ formami przywiązywania, za pomocą których teksty nas kuszą i zjednują, zaskakują i uwodzą ${ }^{6}$. Te przywiązania świadczą o naszym życiu społecznym, zachęcają nas do refleksji nad właściwościami dzieł sztuki: nad tym, co sprawia, że sięgamy po książkę albo wciągamy się w film. Podzielam przekonanie Latoura, że dominujące style analiz akademickich często nie pozwalają uchwycić natury naszych powiązań z tekstami, a takie uchwycenie jest niezbędne do lepszego wytłumaczenia, skąd bierze się istotność tych tekstów. Latour podkreśla np. realność zarówno dzieł sztuki, jak i zamieszkujących je bohaterów fikcyjnych, uwzględniając intuicje, które są często lekceważone przez profesjonalnych badaczy jako naiwne. Była już mowa o jego braku zainteresowania podziałem na język i świat: pytanie, czy fikcja odzwierciedla czy zniekształca kontekst społeczny, znika z pola widzenia. Nie jesteśmy też, według Latoura, oddzieleni kordonem od rzeczywistości przez nieprzekraczalną ścianę znaczeń i tekstualności. Zadaniem badacza jest raczej podążanie za aktorami przez sieć słów, rzeczy, idei, obrazów i praktyk,

6 R. Felski Uses of literature, Blackwell, Oxford 2008. 
za pomocą których aktorzy są tworzeni. W tym sensie wiersze i obrazy mają w sobie tyle samo ontologicznej realności co azot lub Napoleon - są aktorami wplecionymi w sieci powiązań, wzbudzającymi nasze zaciekawienie i pozwalającymi rzeczom dziać się. Dzieła fikcji, zaznacza Latour, nie „kierują naszej uwagi w stronę iluzji, w stronę fałszu, lecz ku temu, co wytworzone, spójne i realne"7. Jak sugeruje ten dobór słów, z perspektywy teorii aktora-sieci realność i wytwórczość są raczej połączone niż przeciwstawione sobie: Emma Bovary była stworzona przez Gustava Flauberta i rzeszę krytyków, tłumaczy, komentatorów, filmowców i widzów, ale to nie pomniejsza jej realności, przeciwnie - umożliwia ją.

W myśl teorii aktora-sieci sprawczość jest złożona, dlatego powinniśmy unikać wyjaśniania znaczeń tekstów za pomocą pojedynczych przyczyn. Kto wytwarza kogo? Sprawczość jest rozproszona, niepewna i trudna do sprecyzowania. W kontrze do stanowiska, zgodnie z którym znaczenie jest określane tylko przez czytelników, wspólnoty interpretacyjne lub czynniki społeczne, Latour podkreśla również presję ze strony tekstu:

Dzieło sztuki angażuje nas i choć prawdą jest, że wymaga ono interpretacji, to w żadnym momencie nie mamy poczucia, iż możemy z nim "zrobić, co tylko chcemy” [...]. Kiedy ktoś mówi „Uwielbiam Bacha” [...], otrzymuje od Bacha, moglibyśmy niemal powiedzieć: „pobiera” od niego, zasoby potrzebne do wyrażenia podziwu. ${ }^{9}$

Dzieła sztuki zapraszają nas i pobudzają, czasem w sposób zaskakujący i trudny do przewidzenia. Nakierowują czytelników w stronę określonych ścieżek interpretacyjnych, wpływają na ich postrzeganie. Mają własną godność ontologiczną, nie są tylko ekranem, na którym wyświetlamy wcześniej nabyte fantazje i ideologie. Tym samym Latour pomaga nam uwzględnić solidność i żywotność tekstów jako aktorów pozaludzkich, którzy przemieszczają się w czasie i przestrzeni ${ }^{10}$.

B. Latour An inquiry into modes of existence, s. 238.

8 Na temat realności fikcji zob. też przydatne uwagi w: W.B. Warner Reality and the novel: Latour and the uses of fiction, "The Eighteenth Century" 2016 no. 2.

9 B. Latour An inquiry into modes of existence, s. 241. 
Jednocześnie dzieła sztuki potrzebują naszego zaangażowania. Ich istnienie zależy od zainteresowania czytelników bądź widzów, którzy są pośrednikami, konieczną ścieżką, bez której przejścia dzieła zostaną zredukowane do „porażki, straty, zapomnienia: będą porzuconą scenografią, zwiniętym płótnem, bezużytecznym wyposażeniem, wyschniętą paletą, przeżartą przez mole spódniczką baletnicy"11. Stąd bierze się prawdziwa i nieodłączna wieloznaczność sprawczości: tworzymy dzieła sztuki, a jednocześnie one tworzą nas. Co za różnica, czy dajemy się ponieść narracji, czy przewieźć kolejce metra? To nie tak - powiada Latour - że jedno doświadczenie jest fałszywe bądź nierzeczywiste, a drugie prawdziwe; rzecz raczej w tym, że to pierwsze wymaga naszej troski i aktywnego uczestnictwa, a to drugie nie. Badawczy etos pilności, szacunku i wspaniałomyślności wysuwa się na pierwszy plan, aczkolwiek zostaje pozbawiony atrybutów transcendentalnych. Doświadczenie estetyczne nie stoi w opozycji do społeczeństwa, nie przeczy mu (taki język nie ma sensu w myśl koncepcji Latoura), lecz jest stwarzane w sieci powiązań: dzieło sztuki nabiera wyjątkowości dzięki więzom społecznym, a nie przez uwolnienie się od nich.

Niezbędnym terminem w słowniku Latoura jest p o w i ą z a n i e. Stajemy się dosłownie powiązani z przedmiotami sztuki: zaginamy kartki w książkach, z którymi krążymy po mieście, zakładamy na uszy słuchawki, z których wydobywają się słowa, przewozimy z jednego wynajmowanego mieszkania do drugiego widokówkę z Matisse'em, która spoczywa na naszym biurku. Takie teksty tworzą Umwelt - zorganizowaną wokół ciała sieć relacji, złożoną z rzeczy mających dla nas znaczenie. Powiązanie odnosi się także do emocji: oczarowania dziełem fikcji, rozmarzenia się podczas oglądania obrazu, zachwytu nad regułami teorii krytycznej i zasadami czytania akademickiego. Nie da się oddzielić czy odfiltrować rozumu od zawirowań nastrojów i skłonności, materia faktów jest również materią troski ${ }^{12}$. Latour odwodzi nas od prototypu wiedzącego, ironicznego, oderwanego od badanego przedmiotu uczonego. Robi to przy użyciu zarówno argumentów, jak i stylu oraz tonu. Powiązanie jest też faktem ontologicznym, nieuniknionym warunkiem istnienia. Myśl krytyczna często marzy o podmiocie pozbawionym powiązań, wolnym od ograniczeń, wyemancypowanym. Wyboru nie dokonujemy jednak

11 B. Latour An inquiry into modes of existence, s. 248.

12 W oryginale matters of concern, co w kontekście teorii aktora-sieci tłumaczy się na polski zazwyczaj jako „materię rozważań”, ale żeby oddać sens wypowiedzi autorki, zdecydowałem się na jednorazową zmianę przekładu - przyp. tłum. 
między powiązaniem a oderwaniem, między zdeterminowaniem a wolnością, lecz między dobrymi i złymi powiązaniami, takimi, które nam pomagają, i takimi, które nam szkodzą ${ }^{13}$.

Jakie są konsekwencje tego wszystkiego dla literatury i interpretacji? Teoria aktora-sieci podkreśla zarówno konieczność tworzenia opisów świata empirycznego, jak i trudności z tym związane, poniewaź świat ten często staje $\mathrm{w}$ poprzek naszym oczekiwaniom. Obiektywizm nie jest prywatną własnością pozytywistów, twierdzi Latour; jesteśmy kształtowani przez okoliczności, w jakich się znajdujemy, ale to nie sprawia, że nie istnieją lepsze i gorsze opisy rzeczy, z którymi się stykamy ${ }^{14}$. Nie powinniśmy wyczarowywać znaczenia tekstu na podstawie istniejących wcześniej założeń i wyjaśnień - musimy uznać i szczegółowo opisać cechy tekstu, tak samo jak konkretne ścieżki, którymi się on przemieszcza. Teoria aktora-sieci nie wyklucza polityczności - jest mocno zainteresowana konfliktami, asymetriami i walkami - ale jej niechęć do redukcji sprawia, że dyskurs polityczny nie może służyć jako metajęzyk, na który dałoby się przełożyć wszystko inne. Naszym zadaniem jest uwzględnienie jak największej liczby aktorów oraz precyzyjne opisanie form przyczynowości i powiązań (które są także formami translacji), a nie pozostawanie pasażerem na gapę, wykorzystującym istniejące słowniki teoretyczne; wystrzegajmy się dobrze nam znanych -izmów, czekających niecierpliwe w blokach startowych, by w każdej chwili przejąć stery ${ }^{15}$.

Opis nie stoi w opozycji do interpretacji. Latour z pewnością nie ma cierpliwości do filozofii hermeneutycznej chełpiącej się pomysłowością interpretacyjną ludzkiego podmiotu, który stoi naprzeciw niemego i biernego świata. Mimo to francuski socjolog nie odrzuca interpretacji, ale raczej ją poszerza: „Hermeneutyka nie jest przywilejem ludzkim, lecz, rzec można, właściwością samego świata"16. Oznacza to, że niezliczona liczba bytów

B. Latour Factures/Fractures: from the concept of network to the concept of attachment, "Res: Anthropology and Aesthetics" 1999 no. 36, s. 20-31.

14 B. Latour Splatając na nowo, s. 210-211.

Na temat politycznego wymiaru prac Brunona Latoura zob. B. Piekut Actor-networks in music history: clarifications and critiques, "Twentieth-Century Music” 2014 no. 11, s. 1-25. wprawa w egzegezie biblijnej zdobyta podczas pracy nad doktoratem, wpłynęła na jego późniejszą myśl, np. B. Latour Coming out as a philosopher, "Social Studies of Science” 2010 no. 4, s. 599-608. 
uczestniczy w interakcjach, mediacjach, adaptacjach i translacjach: świat nie jest martwą strefą urzeczowienia, znajdujemy w nim równie dużo wieloznaczności co we współczesnych wierszach ${ }^{17}$. Jednocześnie w tej poszerzonej perspektywie nadal ważne jest to, w jaki sposób ludzie nadają znaczenie wierszom lub obrazom, dzięki temu potrafimy zbliżyć się do zrozumienia szczególnego sposobu istnienia sztuki. Można powiedzieć, że interpretacja jest rodzajem silnego powiązania, a dominujące w literaturoznawstwie przekonania nie pozwalają należycie uchwycić jej mechanizmów. W myśl koncepcji Latoura nie zagłębiamy się pod powierzchnię tekstu, aby odzyskać wyparte bądź stłumione znaczenie, nie dystansujemy się też od niego, aby go „zdenaturalizować” i wykazać, że jest konstrukcją społeczną ${ }^{18}$. Rozpada się podział na obdarzonego wiedzą badacza i pozbawiony tej wiedzy tekst - lub naiwnego czytelnika. Czytanie staje się kwestią komponowania i współtworzenia, wypracowywania połączeń między rzeczami, które wcześniej nie były ze sobą związane (pomyślmy na przykład, jak motyw „szalonej kobiety na poddaszu" wpłynął na wczesne badania feministyczne, jak wytworzył nowe i silne sieci powiązań między grupą badaczek feministycznych a korpusem określonych tekstów XIX-wiecznych). Interpretowanie to dodawanie własnego głosu do tekstu: negocjowanie, przywłaszczanie, rozwijanie, przekładanie i nawiązywanie kontaktu. Nacisk jest położony raczej na akt budowania, a nie rozkładania, komponowania, a nie krytyki, podpierania, a nie obalania. Jak podkreśla Graham Harman, negatywność nie odgrywa w myśleniu Latoura praktycznie żadnej roli ${ }^{19}$.

Nacisk, jaki teoria aktora-sieci kładzie na rozproszoną sprawczość, wpływa też na sposób analizy. Co jest istotne dla znaczenia dzieła sztuki? Narzuca się wiele możliwości: „,kaprysy książąt i sponsorów [...], umiejętność wciskania klawiszy fortepianu, reakcje publiczności po premierze, zadrapania na płycie winylowej lub zły humor diwy"20. Zamiast muru oddzielającego wnętrze tekstu od jego zewnętrza napotykamy tłum kłócących się, rozpychających, połączonych ze sobą aktorów, którzy odgrywają swoje role. Jeśli weźmiemy sobie do serca lekcję teorii aktora-sieci, będziemy mniej skłonni

17 S. Connor Spelling things out , "New Literary History” 2014 no. 2, S. 183-197.

18 R. Felski Digging down and standing back, "English Language Notes” 2013 no. 2, s. 7-24.

Harman ujmuje to we właściwym sobie stylu: „Sama idea Latourowskiego traktatu na temat negatywności wywołuje we mnie śmiech". G. Harman The importance of Bruno Latour for philosophy, "Cultural Studies Review" 2007 no. 1, s. 34. 
ślęczeć nad pojedynczym tekstem w celu wydobycia ukrytej w nim obfitości prawd estetycznych, filozoficznych czy socjopolitycznych - nie poddamy się tak łatwo charyzmie badacza literackiego odgrywającego rolę uprzywilejowanego posłańca ${ }^{21}$. Jednocześnie teoria aktora-sieci nie stoi po stronie beznamiętnych socjologicznych analiz systemów literackich, które przyjmują perspektywę z lotu ptaka, sprawiając, że wszystko staje się podobne, rzeczy zlewają się ze sobą, a ważne szczegóły umykają naszej uwadze. Zatem ani czytanie z bliska, ani czytanie z dystansu, lecz czytanie średniego szczebla ${ }^{22}$ - podejście, które nie opiera się ani na nowatorskiej wartości pojedynczego dzieła, ani na ogólnym pojęciu społeczeństwa bądź systemu literackiego, lecz sytuuje się między jednym a drugim. Interpretacja? Tak, bez wątpienia, ale musi to być interpretacja zarówno przedmiotów, jak i mediacji, a nie tylko dzieł literackich, praktyka złożonej lektury wielorakich tekstów, a nie głębokiego i intensywnego wczytywania się w pojedyncze dzieło ${ }^{23}$. Teoria aktora-sieci z jednej stronny oferuje szerszy pogląd na to, co powinniśmy traktować jako ważne w analizie literackiej, z drugiej podkreśla, że tekst nie może być sprowadzony do funkcji zwierciadła, wskaźnika bądź symptomu społecznej całości.

Sojusz teorii aktora-sieci z literaturoznawstwem, jak każdy inny, wymaga translacji, majsterkowania i dyplomacji. Zamiast stosować koncepcję Latoura do badań literackich jednostronnie, powinniśmy naświetlić zarówno zbieżne interesy, jak i możliwe konflikty. Jak pokazałam, pytania związane z czytaniem i interpretacją nie są obce teorii aktora-sieci, nawet jeśli przybierają w niej inną formę. Zamiast angażować się w hermeneutykę podejrzeń, postrzegamy interpretację jako rodzaj wspólnego budowania i komponowania. Zamiast podkreślać oderwanie analityczne, przyznajemy się do naszych powiązań, lekceważąc zużyty podział na czujnych badaczy i naiwnych czytelników. Zamiast demistyfikować zaangażowanie estetyczne, postrzegamy to doświadczenie jako klucz do zrozumienia, w jaki sposób sztuka przyciąga naszą uwagę. Mówiąc krótko, w tym scenariuszu

H. Love Close but not deep: literary ethics and the descriptive turn, "New Literary History" 2010 no. 2, s. 371-392.

22

Wymyśliłam tę frazę jako analogię do koncepcji pojęć średniego szczebla w socjologii literatury Johna Frowa.

23 E. Outka Dead men, walking: actors, networks, and actualized metaphors in Mrs. Dalloway and Raymond, "Novel" 2013 no. 2, s. 253-274. 
literaturoznawstwo nie jest ani chronione, ani obalane, zostaje raczej przeorientowane i skomponowane na nowo ${ }^{24}$.

Przeł. Tomasz Szymon Markiewka

\section{Abstract}

\section{Rita Felski}

UNIVERSITY OFVIRGINIA

Latour and Literary Studies

Felski examines how Bruno Latour's actor-network theory can influence our understanding of literature, especially the relationship between readers and the literary text. Latour guides us towards a causal concept of literature, one that includes an open field for multiple interactions or relationships - also on the emotional level - between the reader and the literary work. These interactions go both ways: from the work to the reader and vice versa.

\section{Keywords}

actor-network theory, Bruno Latour, interpretation, literary studies, fiction

24 Muecke daje ciekawy przykład takiego skomponowania na nowo. S. Muecke Motorcycles, snails, retour: criticism without judgement, "Cultural Studies Review” 2012 no. 1, s. 40-58. Podziękowania dla Stephena Muecke'a, Benjamina Piekuta i Billa Warnera za pomocne uwagi. 